\title{
Efficient Use of Nitrogen and Water in High-density Apple Orchards
}

\author{
D. Neilsen and G.H. Neilsen
}

Additional INDEX words. tree nitrogen demand, drip irrigation, fertigation, evaporative demand, nitrate leaching, Malus domestica

Summary. In irrigated apple orchard systems, the magnitude and timing of plant demand for nitrogen $(\mathrm{N})$ and retention of $\mathrm{N}$ in the root zone to allow root interception are important factors for efficient management of $\mathrm{N}$ fertilizer. Results from five experiments in high-density plantings of apple (Malus domestica) on dwarfing ('Malling 9') rootstocks are reported. All experimental plots received daily drip irrigation and $\mathrm{N}$ applied through the irrigation system (fertigation) with different regimes according to experimental design. Labelled fertilizer applications, whole tree excavation and partitioning and removal of $\mathrm{N}$ in fruit and senescent leaves were used to assess tree $\mathrm{N}$ demand. Nitrogen requirements ranged from 8 to $40 \mathrm{lb} /$ acre $\left(8.8\right.$ to $\left.44 \mathrm{~kg} \cdot \mathrm{ha}^{-1}\right)$ over the first 6 years after planting and $\mathrm{N}$ use efficiency was often low $(<30 \%)$, likely because supply exceeded demand. Annual growth is supported by $\mathrm{N}$ remobilized from storage and taken up by roots. Root uptake of labelled fertilizer was negligible during early spring and the commencement of rapid uptake was associated with the end of remobilization and the start of shoot growth, rendering prebloom fertilizer applications ineffective. Thus timing of $\mathrm{N}$ supply to periods of high demand is crucial for improving efficiency. Comparisons were made to determine the effects on $\mathrm{N}$ leaching and tree $\mathrm{N}$ utilization of irrigation scheduled to meet evaporative demand and irrigation applied at a fixed rate. Water losses beneath the root zone were greater for fixed rate than scheduled irrigation during the coolest months (May, June and September) of irrigation application. Nitrogen leaching followed a similar pattern during times of $\mathrm{N}$ fertigation (May and June). Greater $\mathbf{N}$ use efficiency was also measured for trees when irrigation was scheduled to meet evaporative demand rather than applied at a fixed rate. The most $\mathrm{N}$ efficient management system was for trees receiving a low $\left[50 \mathrm{ppm}\left(\mathrm{mg} \cdot \mathrm{L}^{-1}\right)\right]$ fertigated $\mathrm{N}$ supply, at 0 to 4 or 4 to 8 weeks following bloom with scheduled irrigation.

\footnotetext{
$\mathrm{I}$ mproving nitrogen and water management is important from several perspectives. The potential detrimental effects of misuse of $\mathrm{N}$ in agriculture on both the atmosphere (greenhouse and ozonedepleting gases) and groundwater (nitrate leaching) have been well documented in both the scientific and popular press. In irrigated agriculture, leaching losses of excess $\mathrm{N}$ to groundwater are partially determined by the way in which water is applied and thus, can probably be more readily controlled than in rainfed systems. There is also growing concern in the Pacific northwestern U.S. and southern British Columbia, Canada, about the long term availability of irrigation water supply, particularly in light of changing hydrograph patterns in snow melt watersheds (Leith and Whitfield, 1998) and the need to maintain minimum stream flows for fish habitat.
}

Agriculture and Agri-Food Canada, Pacific Agri-Food Research Centre, Summerland, BC, Canada V0H 1 Z0.

Contribution 2122. This work was supported by the Okanagan Valley Tree Fruit Authority, The Washington Tree Fruit Research Commission and The Matching Investment Initiative Program of Agriculture and Agri-Food Canada. 
In addition to environmental concerns about agricultural water and $\mathrm{N}$ use, there is continued economic pressure on farmers to produce the highest quality fruit and it has been shown previously that excess $\mathrm{N}$ can affect fruit quality (Faust, 1989). Effects may include reduced firmness at harvest and after storage, or reduced red color development when internal ethylene production continues to occur, resulting in fruit which are picked overmature (Fallahi, 1997). Incidence of several storage disorders such as cork spot, bitter pit, internal browning and breakdown(Bramlage etal., 1980; Terblanche et al., 1980) has also been linked to excess N supply. Such detrimental effects of excess $\mathrm{N}$ have been related to increases in fruit size and to shading from vigorously growing shoots amongst other factors. Increased susceptibility to diseases such as fireblight, cased by Erwinia amylovora, has also been attributed to vigorous growth related to $\mathrm{N}$ oversupply (Van der Zwet and Keil, 1979).

In apple orchards, as in most agricultural systems, $\mathrm{N}$ is applied in greater amounts than any other plant nutrient and often, more frequently. However, fruit trees are inefficient in their use of $\mathrm{N}$, recovering around $20 \%$ of applied fertilizer (Weinbaum et al., 1992). Although this may be partially a function of the coarse textured soils in which fruit trees are often grown, delivery of applied $\mathrm{N}$ to the sparse root systems of fruit trees is also an important factor. Apple trees, for example, have rooting densities which are several orders of magnitude less than those of Graminaceae species with which they are in competition (Atkinson, 1980). Even lower rooting densities are found in trees grown on dwarfingrootstocks(Neilsenetal., 1997b). Thus, management of N in apple orchards to meet plant needs and avoid environmental contamination, requires that plant demand is understood and that supply methods are efficient (Tagliavini et al., 1996).

Assessing the amount of $\mathrm{N}$ required by deciduous fruit trees has traditionally been based on leaf $\mathrm{N}$ concentrations. However, responses to $\mathrm{N}$ fertilizer additions such as higher leaf $\mathrm{N}$ concentration, darker leaf color, increased vigor and increased yield may only occur with trees of low $\mathrm{N}$ status as $\mathrm{N}$ uptake is likely restricted in trees of high N status (Weinbaum et al., 1992). Moreover, leaf $\mathrm{N}$ concentration may be unaffected by increased uptake of $\mathrm{N}$ in response to supply if dilution due to increased leaf growth occurs. Thus, leaf $\mathrm{N}$ concentration as a sole method of diagnosis of $\mathrm{N}$ requirement is not satisfactory, particularly when tree $\mathrm{N}$ status is above deficiency. Consequently other methods have been sought to determine tree $\mathrm{N}$ requirements.

Nitrogen is required to support the growth of new tissues of which the developing leaves and fruit are the major sinks. It has been estimated that by midseason, $40 \%$ of total tree $\mathrm{N}$ may be found in leaf tissue in standard mature apple trees (Batjer et al., 1952) and 40\% to $50 \%$ in leaves of young potted trees (Forshey, 1963). Weinbaum et al., (1992) noted that the large woody biomass of field grown fruit trees acts as a deterrent to plant excavation and nutrient analysis, making the determination of seasonal periodicity and amount of annual uptake difficult. However, they also suggested that in large, mature trees, the amount of $\mathrm{N}$ removed in the crop may be a legitimate basis for developing ecologically sound fertilizer recommendations. Attempts have been made to determine the annual demand of apple trees for $\mathrm{N}$ based on the removal of $\mathrm{N}$ from the orchard. In large, mature trees ( 14 to 21 years), around 23 to $24 \mathrm{lb} /$ acre $\left(25\right.$ to $\left.26 \mathrm{~kg} \cdot \mathrm{ha}^{-1}\right) \mathrm{N}$ were removed annually in fruit and prunings when fruit yields were high (Greenham, 1980). When the portion of annual $\mathrm{N}$ uptake that is incorporated into the framework of the tree was included, annual $\mathrm{N}$ removal was estimated as $\mathbf{3 0}$ $\mathrm{lb} /$ acre $\left(33 \mathrm{~kg} \cdot \mathrm{ha}^{-1}\right)$ from 9 to 12 -yearold 'Cox's Orange Pippin' / Malling 7' (M.7) (Greenham, 1980), $47 \mathrm{lb} /$ acre (52 kg.ha-1) from 30-year-old 'Delicious' trees (Batjer et al., 1952) and 55 $\mathrm{lb} /$ acre $\left(60 \mathrm{~kg} \cdot \mathrm{ha}^{-1}\right)$ from 13-year-old 'Starking Delicious'/seedling (Klein et al., 1989). In a semi-intensive planting of 11-year-old 'Golden Delicious'/ 'Northern Spy', $23 \mathrm{lb} /$ acre of $\mathrm{N}$ was removed in fruit and prunings and a further $30 \mathrm{lb} /$ acre in fallen leaves (Haynes and Goh, 1980). Less information is available for younger trees on dwarfing rootstocks in high-density plantings.

Unlike annual crops, $\mathrm{N}$ inputs into woody perennials can affect tree growth and development both in current and subsequent years (Weinbaum et al., 1987). Year to year responses to $\mathrm{N}$ fertilization are affected by processes of storage and remobilization. Nitrogen can be considered to be in storage if it can be remobilized from one tissue and subsequently used for the growth of other tissues (Millard, 1988). During leaf senescence, $\mathrm{N}$ stored in the leaves during the summer is withdrawn, stored overwinter in woody tissue and subsequently remobilized and used for growth in the spring (Millard, 1996). In considering the timing of $\mathrm{N}$ inputs it is thus important to determine when remobilization and root uptake occur.

The efficient delivery of $\mathrm{N}$ to the root systems of dwarf apple trees is dependent on water management. In the past 10 to 15 years, orchard management in the Pacific northwestern U.S. and southern British Columbia has become increasingly precise with the advent of dwarfing rootstocks and highdensity planting systems. In addition, there has been a shift to use of lowpressure microirrigation techniques. Such intensively managed apple orchards with microirrigation systems offer the opportunity to control $\mathrm{N}$ and water inputs, by the application of $\mathrm{N}$ through the irrigation system at specific times and with scheduling of irrigation to meet evaporative demand (Neilsen et al., 1998). This approach makes it possible to improve the efficiency of both water and $\mathrm{N}$ fertilizer use thus reducing leaching losses.

This paper summarizes the results from a series of experiments designed to determine the effects of the role of $\mathrm{N}$ from tree storage and root uptake; rate and timing of $\mathrm{N}$ supply and irrigation management on tree growth and development and $\mathrm{N}$ use in high-density apple orchards typical of the Pacific northwestern U.S. and southern British Columbia, Canada.

\section{Field experiments}

Five field experiments were conducted at the Pacific Agri-Food Research Centre, Summerland British Columbia with several varieties of apple grafted on 'Malling 9' (M.9) dwarfing rootstock. Planting densities were between 1000 and 1336 trees / acre (2470 to 3300 trees/ha). All experiments were planted on Skaha or Osoyoos loamy sand soil (Wittneben, 1986) and received daily drip irrigation. All trials had a randomized complete block design. Only experimental details pertinent to data presented in this paper are given.

Experiment 1. 'Golden Delicious' /M.9 apple trees were planted on 9 Apr. 1997 (Neilsen et al., 2001b). 

quirements based on previous day's evaporation from an atmometer (ETGage Co., Loveland, Colo.) linked to an irrigation system (Parchomchuk et al., 1996). Nitrogen was applied daily over a 6-week period through the irrigation system at three application timings (N1) 2 to $8,(\mathrm{~N} 2) 5$ to 11 and (N3) 8 to 14 weeks after planting as ${ }^{15} \mathrm{~N}$ isotopelabelled calcium nitrate $\left[\mathrm{Ca}\left({ }^{15} \mathrm{NO}_{3}\right)_{2}\right]$ with a ${ }^{15} \mathrm{~N}$ concentration of 1.85 atom\% ( $1.85 \%$ of total $\mathrm{N})$, to give an average $\mathrm{N}$ concentration in the fertigating solution of $112 \mathrm{ppm}$. Trees were harvested at regularintervals after planting, four times planting and in spring (21 May 1998) in year 2. Labelled and unlabelled $\mathrm{N}$ and dry matter content were determined.

EXPeriment 2. 'Elstar'/M.9 apple trees were planted in 1992 (Neilsen et al., 1997a, 2001a). Irrigation was applied at a fixed rate of $2 \mathrm{gal}(8 \mathrm{~L})$ of water per day. In year 3, (1994), $\mathrm{N}$ was supplied as ${ }^{15} \mathrm{~N}$ isotope-labelled ammonium nitrate $\left({ }^{15} \mathrm{NH}_{4}{ }^{15} \mathrm{NO}_{3}\right.$ with a ${ }^{15} \mathrm{~N}$ concentration of 2.1 atom $\%$ ) over a 10 -week period starting 10 Apr. at the rate of $0.7 \mathrm{l} \mathrm{oz} /$ tree $(20 \mathrm{~g} /$ tree) of $\mathrm{N}$. The $\mathrm{N}$ concentration in the irrigation water averaged $36 \mathrm{ppm}$. Detailed, sequential leaf sampling was carried out in 1994 and fruit samples were collected at harvest. In 1995, trees received $0.71 \mathrm{oz} /$ tree of unlabelled $\mathrm{N}$ and after harvest the whole trees were removed and partitioned.Labelled and unlabelled Nand dry matter content were determined for all samples.

EXPERIMENT 3. 'Gala'/M.9 apple trees were planted in 1997. Irrigation was applied to meet daily requirements based on previous day's evaporation from an atmometer (ETGage Co., Loveland, Colo.) linked to an irrigation system. Nitrogen was applied as $\mathrm{Ca}\left(\mathrm{NO}_{3}\right)_{2}$ daily, through the irrigation system, at three application timings (T1) 0 to 4 , (T2) 4 to 8 and (T3) 8 to 12 weeks after full bloom and at two target concentrations of 50 and $200 \mathrm{ppm}$ in the fertigating solution. The amount of $\mathrm{N}$ added varied with the amount of irrigation water applied. In 1999, this ranged from 0.23 to $1.62 \mathrm{oz} /$ tree $(6.5$ to $45.9 \mathrm{~g} /$ tree $)$ and in 2000 from 0.12 to $0.55 \mathrm{oz} /$ tree (3.4 to $15.6 \mathrm{~g} /$ tree). Tree growth measured as trunk cross-sectional area (TSA), fruit yield and $\mathrm{N}$ content and leaf $\mathrm{N}$ content in July and at senescence (October) were measured annually as well as total canopy dry matter. Data for 1999 and 2000 are presented here.
Irrigation was applied to meet daily rein year 1 at 5,8, 11 , and 14 weeks after
EXPeriment 4. 'Gala' /M.9 apple trees were planted in 1993 on a loamy sand soil (Neilsen et al., 1998). In 1993 and 1994 , the trees received daily irrigation at $2 \mathrm{gal} /$ tree. From 1995 to 1998 , irrigation was applied to meet daily requirements based on previous day's evaporation from an atmometer (ETGage Co., Loveland, Colo.) linked to an irrigation system. Nitrogen was applied as $\mathrm{Ca}\left(\mathrm{NO}_{3}\right)_{2}$ daily, through the irrigation system for 8 weeks post full bloom. In 1993 and 1994, N was applied at a concentration of $75 \mathrm{ppm}$ and from 1995 onwards at a concentration of 90 ppm. In 1998, each tree received $2.1 \mathrm{oz}(59 \mathrm{~g})$ of N. In 1998, fruit yield and $\mathrm{N}$ content and leaf $\mathrm{N}$ content in July and at senescence (October) were measured as well as total canopy dry matter.

EXPERIMENT 5. 'Gala' / M.9 were planted in 1997. Irrigation was applied previous day's evaporation from an atmometer (ETGage Co., Loveland, Colo.) linked to an irrigation system (scheduled), or applied daily at a fixed rate of $2 \mathrm{gal} /$ tree (unscheduled). Nitrogen was applied as $\mathrm{Ca}\left(\mathrm{NO}_{3}\right)_{2}$ daily, through the irrigation system at a concentration of $50 \mathrm{ppm}$ in the fertigating solution. In 1998 trees under scheduled irrigation received $0.56 \mathrm{oz}(15.9 \mathrm{~g})$ of $\mathrm{N}$ and trees under unscheduled irrigation received $1.31 \mathrm{oz}(37.1 \mathrm{~g})$ of $\mathrm{N}$. Tree growth (TSA), fruit yield and N content and leaf $\mathrm{N}$ content in July and at senescence (October) were measured annually as well as total canopy dry matter.

Table 1.Total nitrogen content of young appletrees on 'Malling 9'(M.9) dwarfing rootstock.

\begin{tabular}{|c|c|c|c|}
\hline \multirow[b]{2}{*}{ Expt. } & \multirow[b]{2}{*}{ Variety } & \multicolumn{2}{|c|}{ Ncontent } \\
\hline & & oz (g)/tree & lb/acre ${ }^{\mathrm{z}}\left(\mathrm{kg}_{\mathrm{kha}} \mathrm{h}^{-1}\right)$ \\
\hline 1 & Golden Delicious/M.9 at planting & $0.08(2.27)$ & $6.7(7.4)$ \\
\hline 1 & Golden Delicious/M.9 end of year 1 & $0.29(8.22)$ & $24.2(26.6)$ \\
\hline 2 & Elstar/M.9 end of year 4 & $0.70(19.85)$ & $58.5(64.4)$ \\
\hline
\end{tabular}

${ }^{\mathrm{z}}$ Assumes tree density of 1336 trees/acre (3300 trees/ha).

Table 2. Estimates of annual nitrogen requirements of apple trees on 'Malling 9' (M.9) dwarfing rootstock; nitrogen removal in fruit and senescent leaves.

\begin{tabular}{lllc} 
& & \multicolumn{2}{c}{$\mathbf{N}$ content } \\
\cline { 3 - 4 } Expt. & Variety & oz (g)/tree & lb/acre $^{\mathbf{z}} \mathbf{( \mathbf { k g } \cdot \mathbf { h } \mathbf { a } ^ { \mathbf { - 1 } } \mathbf { ) }}$ \\
\hline 1 & Golden Delicious/M.9 end of year $1^{\mathrm{y}}$ & $0.10(2.84)$ & $8.4(9.2)$ \\
2 & Elstar/M.9 end of year 4 & $0.36(10.21)$ & $30.1(33.1)$ \\
3 & Gala/M.9 end of year 3 & $0.37(10.49)$ & $31.3(34.4)$ \\
4 & Gala/M.9 end of year 6 & $0.43(12.19)$ & $36.2(39.8)$
\end{tabular}

${ }^{\mathrm{z}}$ Assumes tree density of 1336 trees/acre (3300 trees/ha).

yLeaves only.

Data for 1998 are presented here. Losses of $\mathrm{N}$ and water beneath the root zone were measured using passive capillary wick samplers (Boll et al., 1992).

\section{Nitrogen management}

Demand for nitrogen. The total $\mathrm{N}$ content of dwarf apple trees was quite low, ranging from $0.08 \mathrm{oz}(2.3 \mathrm{~g})$ per tree for newly planted trees to $0.7 \mathrm{oz}$ $(19.8 \mathrm{~g})$ per tree for 4-year-old trees (Table 1).Atplanting densities of around 1336 trees/acre (3300 trees/ha), the tree $\mathrm{N}$ content ranged from 7 to $59 \mathrm{lb} /$ acre $\left(7.7\right.$ to $\left.60 \mathrm{~kg} \cdot \mathrm{ha}^{-1}\right)$. Older trees may have a somewhat higher $\mathrm{N}$ content, but maximum tree size is often reached by year 6 in high-density apple plantings. Recommended annual rates of $\mathrm{N}$ application for young dwarf apple trees range from 80 to $160 \mathrm{lb} /$ acre (88 to 176 $\left.\mathrm{kg} \cdot \mathrm{ha}^{-1}\right)($ Okanagan Valley Tree Fruit Authority, 1993) indicating a large potential oversupply when compared with actual tree uptake. Weinbaum et al. (1992) estimated that annual overapplication of $\mathrm{N}$ to apple orchards in California ranged from about 23 to $335 \mathrm{lb} /$ acre ( 25 to $369 \mathrm{~kg} \cdot \mathrm{ha}^{-1}$ ).

A large proportion of total tree $\mathrm{N}$ is used to support annual growth. Weinbaum et al. (1987) estimated that $40 \%$ to $50 \%$ of total tree $\mathrm{N}$ in large trees is replaced annually by root uptake. Neilsen at al. (200lb) found a similar relationship for young, dwarfapple trees. Thus a useful estimate of tree $\mathrm{N}$ demand may be the amount partitioned to annual growth. The amount of $\mathrm{N}$ reto meet daily requirements based on

Hortechnology • January-March $2002 \quad$ 12(1) 
(A)

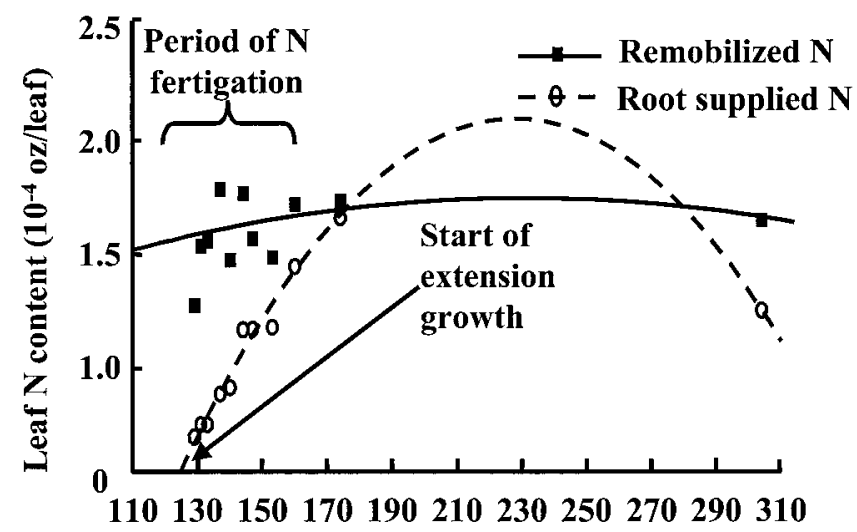

Day of the year
(B)

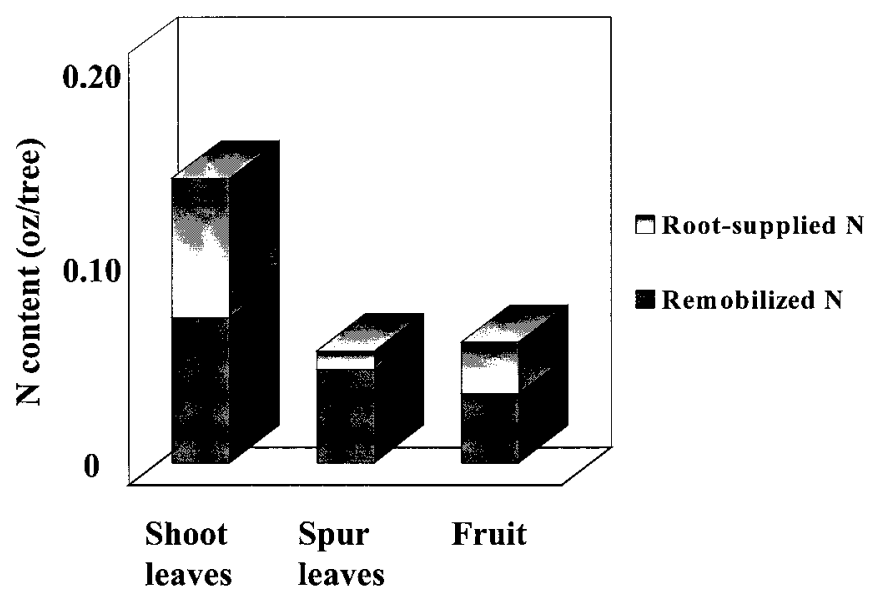

Fig. 1. Sources of nitrogen (A) in shoot leaves throughout the growing season and (B) in shoot leaves, spur leaves, and fruit at the end of the growing season for 3-year-old 'Elstar' apple trees on 'Malling 9' rootstock $($ Expt. 2$) ; 10^{-4} \mathrm{oz}^{2} \mathbf{2 . 8} \times 10^{-3} \mathrm{~g}$; $1.00 \mathrm{oz}=28.35 \mathrm{~g}$.

moved in fruit and senescent leaves has been calculated for dwarf apple trees of different ages and ranged from 8.4 to $36.2 \mathrm{lb} /$ acre $\left(9.2\right.$ to $\left.39.8 \mathrm{~kg} \cdot \mathrm{ha}^{-1}\right)($ Table 2).

SUPPLY OF NITROGEN FOR GROWTH. Early spring growth of deciduous trees is supported by $\mathrm{N}$ remobilized from storage in woody tissue and $\mathrm{N}$ taken up by the roots (Millard, 1996). Data for 3year-old 'Elstar' /M.9 apple trees (Expt.

2 ) indicated that remobilization of $\mathrm{N}$ from storage was largely completed by the start of shoot extension growth (Fig. IA) and contributed around 50\% of the $\mathrm{N}$ in shoot leaves, $90 \%$ of the $\mathrm{N}$ in

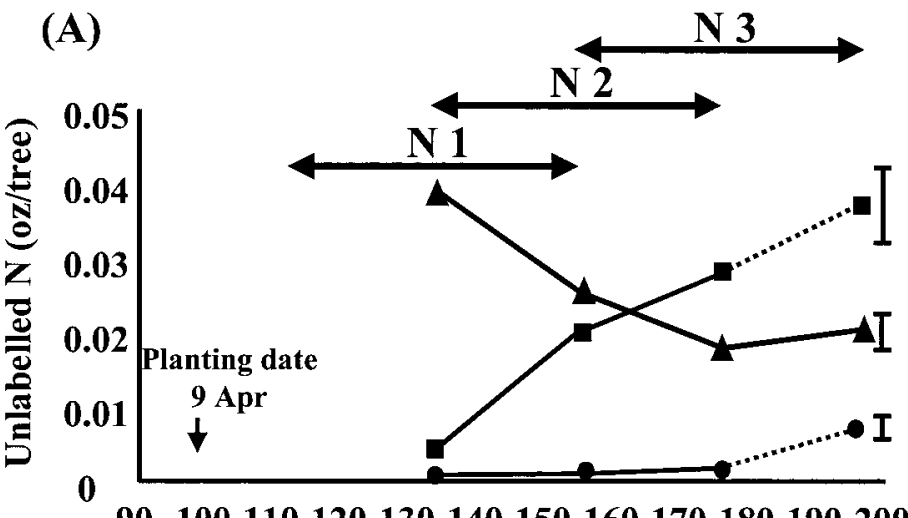

$\rightarrow$ Woody tissue

$\begin{array}{llllllllllllll}90 & 100 & 110 & 120 & 130 & 140 & 150 & 160 & 170 & 180 & 190 & 200\end{array}$

$\rightarrow-$ Shoots

$\rightarrow$ Roots

(B)

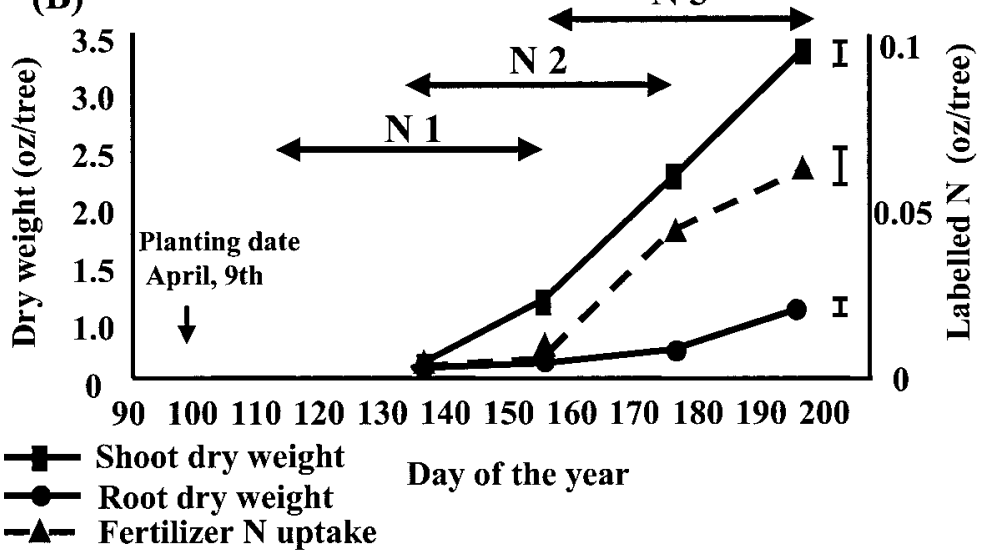

spur leaves that subtend the fruit and about $60 \%$ of the $\mathrm{N}$ in the fruit (Fig. 1B). Although fertilizer $\mathrm{N}$ was available before shoot development it is apparent that little was taken up until shoot development started (Fig. 1A). Thus, as the shoot leaf canopy is the largest sink for $\mathrm{N}$ in most dwarf apple trees, application of $\mathrm{N}$ before root uptake occurs is likely to result in inefficient fertilizer use. In newly planted 'Golden Delicious' / M.9 (Expt. 1), around half of the stored (unlabelled) tree $\mathrm{N}$ was remobilized from woody tissue and into new roots and shoots by $80 \mathrm{~d}$ after planting (Fig. 2A). However, root uptake of fertilizer (labelled) $\mathrm{N}$ did not occur until after shoot growth had started (Fig. 2B). Thus, early $\mathrm{N}$ fertilizer applications $(\mathrm{Nl})$ were likely less efficient than later applications ( $\mathrm{N} 2$ and $\mathrm{N} 3$ ). It is possible that amino acids circulating within the plant during spring $\mathrm{N}$ remobilization may suppress $\mathrm{N}$ uptake. Sharp increases in amino acid concentrations have been observed in the xylem sap of apple trees during spring remobilization (Malaguti et al., 2001) and an inverse relationship

Fig. 2. Relationshipof Napplication timing N1, N2 and N3 (2-8,5-11, and 8-14 weeks after planting, respectively) to (A) remobilization of unlabelled $N$ from woody tissueintonew growth (dotted lines represent period when unlabelled $N$ could beboth from remobilization and rootuptake) and (B) uptakeoffertilizer (labelled) N with respect to growth in newly planted 'Golden Delicious' apple trees on 'Malling 9' rootstock (Expt. 1). Vertical bars represent the average \pm 1 SE; $1.00 \mathrm{oz}=28.35 \mathrm{~g}$. 
Table 3. Effect of timing and rate of nitrogen $(N)$ supply on nitrogen inputs and removal in fruit and senescentleaves for three and 4year-old 'Gala' apple trees on 'Malling''(M.9) dwarfing rootstock(Expt.3).

\begin{tabular}{|c|c|c|c|c|c|c|}
\hline \multirow{2}{*}{$\begin{array}{l}\text { Time of } \\
\text { application }\end{array}$} & \multicolumn{4}{|c|}{$\begin{array}{c}\text { Annual } N \text { additions } \\
\text { oz }(\mathrm{g}) / \text { tree }\end{array}$} & \multicolumn{2}{|c|}{$\begin{array}{c}\text { Annual N removal } \\
\text { oz }(\mathrm{g}) / \text { tree } \\
\end{array}$} \\
\hline & $\mathbf{N 1} \mathbf{r}^{\mathbf{z}}$ & N2 & N1 & Efficiency $^{x}$ & N2 & Efficiency $^{x}$ \\
\hline $\mathrm{Tl}^{\mathrm{y}}$ & $0.25(7.1)$ & $0.57(16.2)$ & $0.29(8.2)$ & $116 \%$ & $0.40(11.3)$ & $70 \%$ \\
\hline $\mathrm{T} 2$ & $0.23(6.5)$ & $1.09(30.9)$ & $0.37(10.5)$ & $61 \%$ & $0.43(12.2)$ & $39 \%$ \\
\hline $\mathrm{T} 3$ & $0.40(11.3)$ & $1.62(45.9)$ & $0.35(9.9)$ & $88 \%$ & $0.41(11.6)$ & $25 \%$ \\
\hline $\mathrm{N}$ & & & \multicolumn{4}{|c|}{ * } \\
\hline $\mathrm{T}$ & & & \multicolumn{4}{|c|}{ NS } \\
\hline $\mathrm{N} \times \mathrm{T}$ & & & \multicolumn{4}{|c|}{ NS } \\
\hline \multicolumn{7}{|l|}{ Year 4} \\
\hline $\mathrm{Tl}^{\mathrm{y}}$ & $0.18(5.1)$ & $0.55(15.6)$ & $0.25(7.1)$ & $137 \%$ & $0.33(9.4)$ & $60 \%$ \\
\hline $\mathrm{N}$ & & & \multicolumn{4}{|c|}{$* *$} \\
\hline $\mathrm{T}$ & & & \multicolumn{4}{|c|}{ NS } \\
\hline $\mathrm{N} \times \mathrm{T}$ & & & \multicolumn{4}{|c|}{ NS } \\
\hline
\end{tabular}

${ }^{\mathrm{z}} \mathrm{Nl}=50 \mathrm{ppm}$ and $\mathrm{N} 2=200 \mathrm{ppm}$ nitrogen in the fertigating solution.

$\mathrm{y} \mathrm{T} 1=0-4 ; \mathrm{T} 2=4-8 ; \mathrm{T} 3=8-12$ weeks after full bloom.

xercentages of total applied nitrogen found in leaves and fruit.

Ns, ${ }^{*},{ }^{* *}$ Nonsignificant or significant at $P<0.05$ or 0.01 , respectively.

has been observed between the concentration of $\mathrm{N}$ contained in amino acids in the vasculature of field grown almond trees and the capacity of those trees to take up soil N (Youssefi et al., 2000).

EFficiency of supply. In irrigated systems, efficient use of $\mathrm{N}$ is de- pendent on matching supply (amount and timing of applications) to demand, and also on retaining $\mathrm{N}$ in the root zone in order to facilitate interception by the plant. Nitrogen use efficiency can only be directly assessed by use of labelled fertilizer and whole tree excavation. For example, in Expt. 2, N uptake accounted for around $22 \%$ of added fertilizer (Neilsen et al., 2001b). In Expt. 1, whole tree analysis in the second year indicated that the amount of fertilizer $\mathrm{N}$ taken up by trees receiving $\mathrm{N}$ at time $\mathrm{N} 3$ was 1.58 times greater than trees receiv-

Table 4. Effect of timing and rate of nitrogen (N) supply on growth, fruiting and tree $\mathbf{N}$ status for 3 and 4-year-old 'Gala' apple trees on 'Malling 9' (M.9) dwarfing rootstock (Expt. 3).

\begin{tabular}{|c|c|c|c|c|c|c|}
\hline $\begin{array}{l}\mathbf{N} \\
\text { time }\end{array}$ & \multicolumn{2}{|c|}{$\begin{array}{c}\text { Trunk } \\
\text { cross-sectional } \\
\text { area } \\
{\left[\operatorname{inch}^{2}\left(\mathrm{~cm}^{2}\right)\right]}\end{array}$} & \multicolumn{2}{|c|}{$\begin{array}{c}\text { Yield } \\
\text { lb }(\mathrm{kg}) / \text { tree }\end{array}$} & \multicolumn{2}{|c|}{$\begin{array}{c}\text { Leaf } N \\
(\% \text { dry wt) }\end{array}$} \\
\hline \multicolumn{7}{|l|}{ Year 3} \\
\hline $\mathrm{T}^{\mathrm{y}}$ & $1.35(8.71)$ & $1.49(9.61)$ & $10.2(4.6)$ & $11.4(5.2)$ & 2.35 & 2.63 \\
\hline SE & \multicolumn{2}{|c|}{$0.11(0.71)$} & \multicolumn{2}{|c|}{$1.57(0.71)$} & \multicolumn{2}{|c|}{0.069} \\
\hline $\mathrm{N}$ & \multicolumn{2}{|c|}{ NS } & \multicolumn{2}{|c|}{ NS } & \multicolumn{2}{|c|}{ * } \\
\hline $\mathrm{T}$ & \multicolumn{2}{|c|}{ NS } & \multicolumn{2}{|c|}{ NS } & \multicolumn{2}{|c|}{ NS } \\
\hline $\mathrm{N} \times \mathrm{T}$ & \multicolumn{2}{|c|}{ NS } & \multicolumn{2}{|c|}{ NS } & \multicolumn{2}{|c|}{ NS } \\
\hline \multicolumn{7}{|l|}{ Year 4} \\
\hline $\mathrm{N}$ & \multicolumn{2}{|c|}{ NS } & \multicolumn{2}{|c|}{ NS } & \multicolumn{2}{|c|}{ NS } \\
\hline $\mathrm{T}$ & \multicolumn{2}{|c|}{ NS } & \multicolumn{2}{|c|}{ NS } & \multicolumn{2}{|c|}{ NS } \\
\hline $\mathrm{N} \times \mathrm{T}$ & \multicolumn{2}{|c|}{ * } & \multicolumn{2}{|c|}{ * } & \multicolumn{2}{|c|}{ NS } \\
\hline
\end{tabular}

${ }^{\mathrm{z}} \mathrm{Nl}=50 \mathrm{ppm}$ and $\mathrm{N} 2=200 \mathrm{ppm} \mathrm{N}$ in the fertigating solution.

$\mathrm{y}_{\mathrm{T} 1}=0-4 ; \mathrm{T} 2=4-8 ; \mathrm{T} 3=8-12$ weeks after full bloom.

Ns, ${ }^{*}$ Nonsignificant or significant at $P<0.05$, respectively. 
(A)

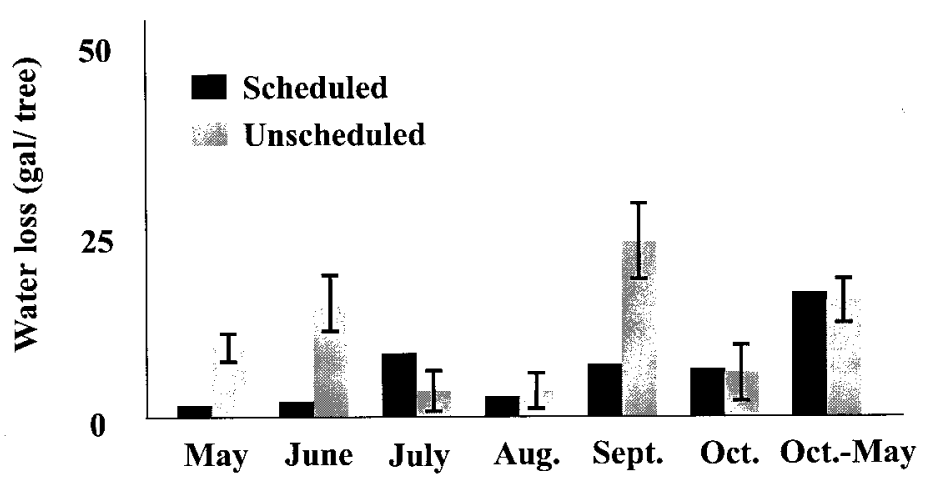

(B)

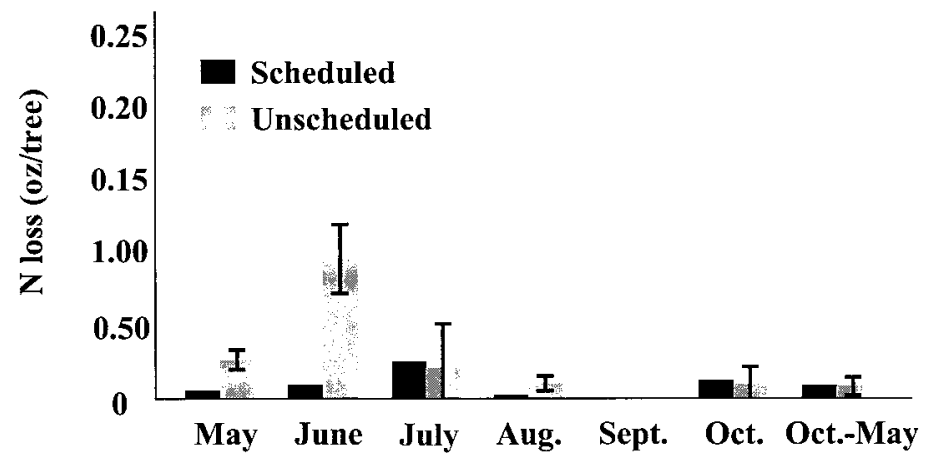

Fig. 3. Seasonal (A) waterand (B) nitrogen losses beneath the rootzone for 2-year-old 'Gala' appletrees on 'Malling 9 'rootstock in response to irrigation either applied tomeet evaporative demand (scheduled) or at a fixed daily rate (unscheduled) (Expt. 5). Vertical bars represent the average $\pm 1 \mathrm{sE} ; 1.00 \mathrm{oz}=$ $28.35 \mathrm{~g}, 1 \mathrm{gal}=3.8 \mathrm{~L}$.

ing $\mathrm{N}$ at time $\mathrm{Nl}$ (Neilsen et al., 200la), as the earlier (Nl) application time coincided with the period of $\mathrm{N}$ remobilization and low root uptake (Fig. 2).

In Expt. 3, losses of $\mathrm{N}$ in senescent leaves and fruit were used to characterize annual $\mathrm{N}$ demand and to relate demand to timing and rate of $\mathrm{N}$ supply (Table 3 ). As $\mathrm{N}$ additions were based on the concentration of $\mathrm{N}$ in the fertigating solution (N1) and (N2) and because irrigation was scheduled to meet evapo- rative demand, the amount of $\mathrm{N}$ applied varied in each of the 4-week fertilizer timing treatments $(\mathrm{T} 1, \mathrm{~T} 2, \mathrm{~T} 3)$. The amount of $\mathrm{N}$ removed in senescent leaves + fruit was higher in both years for trees receiving the higher $(\mathrm{N} 2)$ rate of $\mathrm{N}$ (Table 3). However, taking into account the percentages of added $\mathrm{N}$ removed in the senescent leaves + fruit, there was potential oversupply of $\mathrm{N}$ in the high $\mathrm{N}$ treatment and potential undersupply in the low $\mathrm{N}$ treatment. There was no effect of timing $(\mathrm{T})$ of $\mathrm{N}$ supply on $\mathrm{N}$ removal. Assuming a tree planting density of 1336 trees/acre (3300 trees/ha), N removal rates varied between 20 and $30 \mathrm{lb} /$ acre (22 and 33 $\left.\mathrm{kg} \cdot \mathrm{ha}^{-1}\right)$. Higher application rates of $\mathrm{N}$ (N2) did not necessarily lead to increases in growth and yield in these trees
(Table 4) as similar growth and yields were obtained with both application rates of $\mathrm{N}$. The major effect of extra $\mathrm{N}$ supply was on $\mathrm{N}$ storage in leaves. Leaf $\mathrm{N}$ concentrations were higher for trees receiving the higher $\mathrm{N}$ rate in year 3 , although this effect had disappeared by year 4 . However, all trees had leaf $\mathrm{N}$ concentrations that were in the sufficient range (British Columbia Ministry of Agriculture, Fisheries and Food, 1996).

In addition to matching $\mathrm{N}$ supply to demand at times when $\mathrm{N}$ uptake is most likely, retention of $\mathrm{N}$ in the root zone is an important factor in efficient fertilizer management. In Expt. 5, the effects of irrigation applied at fixed rate (unscheduled) and irrigation applied to meet evaporative demand (scheduled) on $\mathrm{N}$ leaching and crop $\mathrm{N}$ use were compared.

Volume of water and nitrate $\mathrm{N}$ concentration were measured throughout the growing season from passive capillary wick samplers. Differences in water losses beneath the root zone were greatest in the coolest months, May, June, and September when fixed rate applications greatly exceeded evaporative demand (Fig. 3A). There was little effect of irrigation method on water losses over winter, from mid-October through May. Losses of $\mathrm{N}$ beneath the root zone were greatest for fixed rate irrigation during the period of fertilizer application at times when water applications were poorly matched with demand, i.e., May and June (Fig. 3B).

The total amount of water applied with irrigation scheduled to meet evaporative demand was $50 \%$ of that applied under fixed rate irrigation (Table 5). As $\mathrm{N}$ was applied at a fixed target concentration in the fertigating solution (about $50 \mathrm{ppm}$ ), $\mathrm{N}$ additions were also considerably less (around 43\%) for scheduled compared with unscheduled irrigation. Despite differences in the amounts of $\mathrm{N}$

Table 5. Water and nitrogen additions, nitrogen removal in senescent leaves and fruit, growth, yield and leaf nitrogen content of 2-yearold 'Gala' appletrees on 'Malling9' (M.9) dwarfing rootstock receiving irrigation either applied to meet evaporative demand (scheduled) or at a fixed daily rate (unscheduled) (Expt.5).

\begin{tabular}{|c|c|c|c|c|c|c|}
\hline Irrigation & $\begin{array}{c}\text { Water } \\
\text { added } \\
\text { gal (L)/tree }\end{array}$ & $\begin{array}{c}\mathbf{N} \\
\text { added } \\
\text { oz (g)/tree }\end{array}$ & $\begin{array}{c}\mathbf{N} \\
\text { removal } \\
\text { oz }(\mathrm{g}) / \text { tree }\end{array}$ & $\begin{array}{l}\mathbf{T C A} \\
\text { inch }^{2} \\
\left(\mathbf{c m}^{2}\right) \\
\end{array}$ & $\begin{array}{c}\begin{array}{c}\text { Yield } \\
\text { lb } \\
(\mathrm{kg}) / \text { tree }\end{array} \\
\end{array}$ & $\begin{array}{c}\begin{array}{c}\text { Leaf } \\
N \\
\text { (\% dry wt) }\end{array} \\
\end{array}$ \\
\hline Scheduled & $171(647)$ & $0.56(15.9)$ & $0.21(5.6)$ & $0.92(5.9)$ & 3.75 (1.7) & 2.38 \\
\hline Unscheduled & $345(1306)$ & $1.31(37.1)$ & $0.24(6.8)$ & $0.94(6.1)$ & $2.65(1.2)$ & 2.30 \\
\hline SE & & & $0.03(0.85)$ & $0.05(0.32)$ & $0.53(0.24)$ & 0.054 \\
\hline Significance & & & NS & NS & NS & NS \\
\hline
\end{tabular}


added, there was no difference in the amount of $\mathrm{N}$ removed in leaves and fruit between the trees receiving the two types of irrigation. However, $38 \%$ of the amount of added $\mathrm{N}$ was found in leaves and fruit of trees receiving scheduled irrigation compared with $18 \%$ in trees receiving unscheduled irrigation. Using a tree planting density of 1336 tree/acre (3300 trees/ha) N removal rates for these second yeartreeswere around 18 to $20 \mathrm{lb} /$ acre $\left(22\right.$ to $\left.33 \mathrm{~kg} \cdot \mathrm{ha}^{-1}\right)$. Similarly, there were no effects of irrigation method on growth, yield or leaf $\mathrm{N}$ concentration in these trees. The more effective use of applied $\mathrm{N}$ under scheduled irrigation in this experiment can likely be attributed to longer retention time in the root zone. This is of particularimportance for sparsely rooted dwarf apple trees.

\section{Conclusion}

Using a variety of techniques to assess plant $\mathrm{N}$ demand including whole tree excavations, labelled fertilizer $\mathrm{N}$ uptake and removal of $\mathrm{N}$ in fruit and senescent leaves, it is apparent that apple trees grown on M.9 rootstocks have low requirements for $\mathrm{N}$, ranging from 8 to $40 \mathrm{lb} /$ acre $\left(8.8\right.$ to $\left.44 \mathrm{~kg} \cdot \mathrm{ha}^{-1}\right)$ each year, over the first 6 years after planting. This is considerably less than recommended rates of application. It is also apparent that apple trees on M.9 rootstocks are inefficient users of applied $\mathrm{N}$ fertilizer over the season, thus matching the timing of supply to periods of high demand is important. Annual growth of apple trees is supported by both $\mathrm{N}$ remobilized from storage in the tree and $\mathrm{N}$ supplied by the roots. Root uptake of $\mathrm{N}$ may be inhibited during remobilization, which occurs early in the spring, and rapid uptake of soil $\mathrm{N}$ is associated with the initiation of shoot growth. Thus, very early spring applications of $\mathrm{N}$ may be ineffective. Another factor which influences efficiency of $\mathrm{N}$ fertilizeruse is the movement of $\mathrm{N}$ through the root zone. In irrigated systems, if water is added to meet plant demand, water and $\mathrm{N}$ movement through the root zone can be reduced, and $\mathrm{N}$ leaching losses minimized.

\section{Literature cited}

Atkinson, D. 1980. The distribution and effectiveness of the roots of tree crops. Hort. Rev. 2:424-490.

Batjer, L.P., B.L. Rogers, and A.H. Thompson. 1952. Fertilizer applications as related to nitrogen, phosphorus, potassium, calcium and magnesium utilization by apple trees. Proc. Amer. Soc. Hort. Sci. 60:1-6.
British Columbia Ministry of Agriculture, Fisheries and Food. 1996. Tree fruit production guide for interior districts. BCMAFF, Victoria.

Boll, J., T.S. Steenhuis, and J.S. Selker. 1992. Fiberglass wicks for sampling water and solutes in the vadose zone. Soil Sci. Soc. Amer. J. 56:701-707.

Bramlage, W.J., M. Drake, and W.J. Lord. 1980. The influence of mineral nutrition on the quality and storage performance of pome fruits grown in North America, p. 29-39. In: D. Atkinson, J.E. Jackson, R.O. Sharples, and W.M. Waller (eds.). Mineral nutrition of fruit trees, Butterworths, Sevenoaks, U.K.

Faust, M. 1989. Physiology of temperate zone fruit trees. Wiley, New York.

Fallahi, E. 1997. Preharvest nitrogen optimization for maximizing yield and post-harvest fruit quality of apples. Acta Hort. 448:415-419.

Forshey, C.G. 1963. A comparison of soil nitrogen fertilization and urea sprays as sources of nitrogen for apple trees in sand culture. Proc. Amer. Soc. Hort. Sci. 83:332-345.

Greenham, D.W.P. 1980. Nutrient cycling: The estimation of orchard nutrient uptake, p. 345352. In: D. Atkinson, J.E. Jackson, R.O. Sharples, and W.M. Waller (eds.). Mineral nutrition of fruit trees. Butterworths, Sevenoaks, U.K.

Haynes, R.J. and K.M. Goh. 1980. Distribution and budget of nutrients in a commercial apple orchard. Plant and Soil 56:445-457.

Klein, I., I. Levin, B. Bar-Yosef, R. Assaf, and A. Berkovitz. 1989. Drip nitrogen fertigation of 'Starking Delicious' apple trees. Plant and Soil 119:305-314.

Leith, R.M. and P.H. Whitfield. 1998. Evidence of climate change effects on the hydrology of streams in south-central B.C. Can. Water Resources J. 23:210-230.

Malaguti, D., P. Millard, R. Wendler, A. Hepburn, and M. Tagliavini. 2001. Translocation of amino acids in the xylem of apple (Malus domestica Borkh.) trees in spring as a consequence of both $\mathrm{N}$ remobilisation and root uptake. J. Expt. Bot. 52:1665-1671.

Millard, P. 1988. The accumulation and storage of nitrogen by herbaceous plants. Plant Cell Environ. 11:1-8.

Millard, P. 1996. Ecophysiology of the internal cycling of nitrogen for tree growth. J. Plant Nutr. Soil Sci. 159:1-10.

Neilsen, D., P. Millard, G.H. Neilsen, and E.J. Hogue. 1997a. Sources of $\mathrm{N}$ for leaf growth in a high density apple (Malus domestica) orchard irrigated with an ammonium nitrate solution. Tree Physiol. 17:733-739.

Neilsen, D., P. Millard, L.C. Herbert, G.H. Neilsen, E.J. Hogue, P. Parchomchuk, and B.J. Zebarth. 2001a. Remobilization and uptake of $\mathrm{N}$ by newly planted apple trees (Malus domestica) in response to irrigation method and timing of $\mathrm{N}$ application. Tree Physiol. 21:513-521.
Neilsen, D., P. Millard, G.H. Neilsen, and E.J. Hogue. 200lb. Nitrogen uptake, efficiency of use and partitioning for growth in young apple trees. J. Amer. Soc. Sci. Hort. Sci. 126:144150.

Neilsen, D., P. Parchomchuk, G.H. Neilsen, and E.J. Hogue. 1998. Using soil solution monitoring to determine the effects of irrigation management and fertigation on nitrogen availability in high-density apple orchards. J. Amer. Soc. Sci. Hort. Sci. 123:706-713.

Neilsen, G.H., P. Parchomchuk, R. Berard, and D. Neilsen. 1997b. Irrigation frequency and quantity affect root and top growth of fertigated 'McIntosh' apple on M.9, M.26 and M.7 rootstock. Can. J. Plant Sci. 77:133-139.

Okanagan Valley Tree Fruit Authority. 1993. Fertigation guidelines in high density apples and apple nurseries in the Okanagan-Similkameen valleys. Okanagan Valley Tree Fruit Authority, Summerland, B.C., Canada.

Parchomchuk P., R.C. Berard, and T.W. Van der Gulik. 1996. Automated irrigation scheduling using an electronic atmometer, p. 10991104. In: C.R. Camp, E.J. Sadler, and R.E. Yoder (eds.). Evapotranspiration and irrigation scheduling. Amer. Soc. Agr. Eng. Proc. Intl. Conf., San Antonio, Texas.

Tagliavini, M., D. Scudellazi, B. Marangoni, and M. Toselli. 1996. Nitrogen fertilization management in orchards to reconcile productivity and environmental aspects. Fert. Res. 43:93-102.

Terblanche, J.H., K.H. Gurgen, and I. Hesebeck. 1980. An integrated approach to orchard nutrition and bitter pit control, p. 71-82. In: D. Atkinson, J.E. Jackson, R.O. Sharples, and W.M. Waller (eds.). Mineral nutrition of fruit trees, Butterworths, Sevenoaks, U.K.

Van der Zwet, T. and H.L. Keil. 1979. Fireblight, a bacterial disease of Rosaeceous plants. USDA Sci. Educ. Admin. Agr. Hdbk. 510, Beltsville Md.

Weinbaum, S.A., R.S. Johnson, and T.M. De Jong. 1992. Causes and consequences of over fertilization in orchards. HortTechnology 2:112121.

Weinbaum, S.A., I. Klein, and T.T. Muraoka. 1987. Use of nitrogen isotopes and a lighttextured soil to assess annual contributions of nitrogen from soil and storage pools in mature almond trees. J. Amer. Soc. Hort. Sci. 112:526529 .

Wittneben, U. 1986. Soils of the Okanagan and Similkameen valleys. Rpt. 52. British Columbia Soil Survey, Ministry of Environment, Victoria, B.C., Canada.

Youssefi, F., P.H. Brown, and S.A. Weinbaum 2000. Relationship between tree nitrogen status, xylem and phloem sap amino acid concentrations, and apparent soil nitrogen uptake by almond trees (Prunus dulcis). J. Hort. Sci. Biotechnol. 75:62-68. 